\title{
The Teacher's Perspective on Inclusion in Education: An Analysis of Curriculum Design
}

\author{
Pedro Jurado-de-los-Santos ${ }^{1, *}$, María Jesús Colmenero-Ruiz ${ }^{2}{ }^{(0}$, Rosa Eva Valle-Flórez ${ }^{3}{ }^{(0)}$, \\ Macarena Castellary-López ${ }^{4}$ (D) and Victoria Figueredo-Canosa 4 (D) \\ 1 Department of Applied Pedagogy, Autonomous University of Barcelona, 08193 Barcelona, Spain \\ 2 Department of Pedagogy, University of Jaen, 23071 Jaen, Spain; mjruiz@ujaen.es \\ 3 Faculty of Education, University of León, 24071 León, Spain; revalf@unileon.es \\ 4 Department of Education, University of Almería, 04120 Almería, Spain; mcl142@ual.es (M.C.-L.); \\ vfc310@ual.es (V.F.-C.) \\ * Correspondence: pedro.jurado@uab.cat
}

Citation: Jurado-de-los-Santos, P.; Colmenero-Ruiz, M.J.; Valle-Flórez, R.E.; Castellary-López, M.;

Figueredo-Canosa, V. The Teacher's Perspective on Inclusion in Education An Analysis of Curriculum Design. Sustainability 2021, 13, 4766. https:// doi.org/10.3390/su13094766

Academic Editor: Andrea Weinberg

Received: 18 February 2021

Accepted: 21 April 2021

Published: 23 April 2021

Publisher's Note: MDPI stays neutral with regard to jurisdictional claims in published maps and institutional affiliations.

Copyright: (C) 2021 by the authors. Licensee MDPI, Basel, Switzerland. This article is an open access article distributed under the terms and conditions of the Creative Commons Attribution (CC BY) license (https:// creativecommons.org/licenses/by/ $4.0 /)$.

\begin{abstract}
The study we present is based on the responses given to students with specific educational support needs in compulsory education stages. Focused from the perspective of teachers within the framework of educational inclusion. To this end, the role of teachers and their influence on curriculum design, methodology, and assessment is taken into account. A descriptive and inferential methodological approach is used, with a sample of 2457 teachers from the Spanish context, applying an ad-hoc questionnaire. The results indicate the influence of teachers' socio-demographic variables on the implementation of curriculum design, methodology, and assessment strategies in line with educational inclusion. The conclusions highlight the reactive versus proactive nature of teaching, although the sufficiency of educational practice is considered, characterised by differences according to age, gender, experience, or location of educative centre, among other variables analysed. It is established that improvements can be identified that can be strengthened. Specifically those related to the interests and motivations of students with SEN and their participation in assessment processes.
\end{abstract}

Keywords: inclusive education; compulsory education; curricular design; SEN; assessment

\section{Introduction}

Among the Sustainable Development Goals (SDG) sponsored by the UN in the 2030 Agenda [1], we highlight SDG 4, which refers to the need for all countries to ensure inclusive, equitable, and quality education and promote lifelong learning opportunities for all by 2030 .

Along the same lines, the need for inclusive education has been addressed by international organizations from the Salamanca Statement [2] to the most recent, in 2019, with the Cali Commitment [3] on equity and inclusion in education. In Spain, the Organic Law $2 / 2006$ on Education [4] considers equity as one of the principles of educational inclusion in order to favour equal opportunities. Despite this, educational practices do not follow the guidelines of educational inclusion.

The implementation of educational inclusion is geared towards the removal of barriers. These limit accessibility, presence, participation, and achievement of learning opportunities. In this sense, it will be relevant to analyse how the implementation of the curriculum design is addressed, specifically through the type of methodological strategies used in the classroom and how the assessment system is applied.

Teachers are ultimately responsible for the teaching-learning process that takes place in the classroom. For this reason, it is necessary to know their perspective on the educational reality they have to face. It is necessary to be aware of the action and influence of certain variables in the inclusion process and teachers, such as the ownership of the 
school [5-8], gender [7,9-13], teaching experience, or age of the teachers [14-24], experience with students with SEN [25-27], or the degree and type of support needs of the students [28], and geographical location of the school [8].

According to Casanova [29], curriculum design must be inclusive; it must support each student, being flexible, open, and providing equal opportunities for all. At the same time, it must meet a series of fundamental requirements. The quality of learning must always be maintained, such as planning and systematicity, coherence, democracy, functionality, comprehensiveness and diversification, interdisciplinarity, and interculturality.

Access to the curriculum, as Wehmeyer [30] puts it, is one of the important issues to consider, in what he calls a third generation of inclusive practices. This approach to teaching and learning allows individuals to build on and utilise their particular learning strengths, recognizing that not all students learn in the same way.

The challenges faced by teachers in adjusting curriculum planning, according to Nilsen [31], are those related to collaboration and coordination. Along the same lines, Buli-Holmberg et al. [32] also propose a collaborative perspective to achieve an adequate response to students with SEN, understanding that this is the only successful approach to achieve the inclusion process.

Maphelo and Joyce [33] argue that curriculum design must be flexible, adapting to students' learning styles, learning rates, and interests. Therefore, teachers must be the ones to implement pedagogical strategies that respect each of their students' characteristics [34-38].

Another aspect to highlight for the development of an inclusive curriculum design is the Universal Design for Learning (UDL) or Design for All, created in 1984 by the Centre for Applied Special Technology in the USA [39]. The aim is to use technology to improve the quality of education for all students. There are three fundamental principles guiding SAD, which are associated with the adaptation of processes, resources, and management systems in the mediation and interaction of teaching and learning. It, thus, provides a framework for curriculum design and implementation, based on the provision of multiple forms of representation, expression and engagement in learning. These principles allow for greater flexibility in curriculum design, thus achieving a more open and inclusive curriculum in terms of the design of devices and services [40], as well as proactively, as it allows access and participation for all students, regardless of their needs [41].

At the methodological level, inclusive education advocates the development of an active, constructive, participatory, and collaborative methodology [42]. Echeita and Verdugo [43], Florian et al. [44] point out the importance of the strategies developed by teachers, at a methodological level, that favour inclusion. We highlight the use of different significant didactic strategies, from questioning practices, feedback, peer assessment, self-assessment [45], flexible social organisation in the classroom [46], problem-based learning [47], exploratory learning and cooperative learning [48-50], among others. Similarly, these methodological changes have led to the rise of differentiated and individualised methods $[45,46,48,50,51]$.

With regard to the evaluation of the teaching-learning process, it has traditionally been related to the results obtained by students, giving it a punitive character. However, in recent years, evaluation has acquired a strategic role, providing significant data for the improvement of educational practice oriented towards equity and benefits for students [52].

As Anijovich and Cappelletti [53] point out, "if the conditions of students are always different, if the rhythms and forms of learning are diverse, if the starting points are never homogeneous, what is learned and what is evaluated cannot be standardised but must be differentiated according to the conditions and individual processes of the students" (p. 166). Furthermore, we consider that evaluation must be understood as a tool that enables the teacher to improve the teaching-learning process, thus being able to know whether or not the educational intentions are being achieved. 


\section{Research Questions and Study Objectives}

After reviewing the contributions of research on this topic, three research questions arise that guide our study: how is curriculum design worked on? What conditions do teachers' conditions affect, in educational practice, the methodological adjustment to respond to SEN? and what conditions condition the adaptations they make in assessment?

This paper analyses the opinions of compulsory education teachers on these factors. This affect to curriculum design, methodology, and assessment to facilitate the inclusion of students with specific educational support needs. Based on the different approaches of the Index for Inclusion [54], we investigated what response is given to pupils with specific educational support needs at compulsory education stages. As specific objectives, we set out to find out whether there are differences in the aforementioned curricular elements based on gender, age, location, and ownership of the centre in which they work, years of professional experience and with students with SEN.

\section{Materials and Methods}

\subsection{Research Design}

In this study we used a quantitative methodology, with a non-experimental, correlational and descriptive design, following the classification and guidelines established by García [55], Bisquerra [56], and Martínez [57].

\subsection{Sample}

The study population is 56,284 compulsory education teachers from different autonomous communities in Spain. To calculate the sample size, we used the formula for the sample size of finite populations, with a confidence level of $95 \%$ and a precision range of 2.5\% [58]. The formula indicates a minimum of 1497 subjects to ensure the representativeness of the sample. In this study, 2457 teachers participated according to the criteria indicated in Table 1, based on the characteristics of the population. The representativeness of the sample of our study is, therefore, guaranteed.

Table 2 below shows the frequency and percentage of teachers participating in the study, according to the different autonomous communities.

\subsection{Instruments and Procedure}

For the collection of quantitative data, an ad hoc questionnaire was used, consisting of a Likert-type scale of 58 items with five response options ranging from 1 (never) to 5 (always). The items are grouped into three dimensions: organisational and curricular aspects, teachers and resources, and inclusive culture. This study addresses the items grouped in the sub-dimensions of "Curriculum design" (items 10, 11, and 12); "Methodology" (items 13, 14, and 15) and "Assessment" (items 16, 17, 18, and 19), belonging to the dimension organisational and curricular aspects.

For validation, the first step was a review of the literature and similar instruments, namely The Index for Inclusion [54]. The initial version of the instrument was tested by an expert judgement (12 university professors specialised in the subject and in research) based on the criteria of uniqueness, relevance, and importance. Finally, a pilot test was carried out with compulsory education teachers to ensure the comprehension of the items. The final questionnaire was made up of contributions from all participants.

Construct validity was assessed using Cronbach's Alpha $(\alpha)$ and McDonald's Omega $(\omega)$. The reliability obtained from the questionnaire through the Statistical Package for the Social Sciences (SPSS) version 25 for the Alpha and through JASP for the Omega yielded very similar data: an $\alpha$ value of 0.926 and $\omega=0.928$ for the total scale. In the sub-dimensions analysed in this paper, the reliability of $\alpha=0.877$ and $\omega=0.878$ in "Curriculum design" (items 10, 11, and 12). In "Methodology" (items 13, 14, and 15) $\alpha=0.762$ and $\omega=0.766$. Finally, in the subdimension of "Evaluation" (items 16-19) $\alpha=0.872$ and $\omega=0.883$, indicating a good reliability and high degree of internal consistency of the instrument [59]. 
Table 1. Characterisation of the sample.

\begin{tabular}{|c|c|c|}
\hline \multirow{2}{*}{ Gender } & Women & $66.7 \%$ \\
\hline & Men & $33.3 \%$ \\
\hline \multirow{5}{*}{ Age } & $<30$ & $7.9 \%$ \\
\hline & $30-40$ & $29.5 \%$ \\
\hline & $41-50$ & $30.4 \%$ \\
\hline & $51-60$ & $30.2 \%$ \\
\hline & $>60$ & $2.1 \%$ \\
\hline \multirow{5}{*}{ Years of professional experience } & $0-5$ & $2 \%$ \\
\hline & $6-10$ & $12 \%$ \\
\hline & $11-15$ & $28 \%$ \\
\hline & $16-20$ & $26 \%$ \\
\hline & $21-40$ & $32 \%$ \\
\hline \multirow{5}{*}{ Years of experience with students with SEN } & $0-5$ & $30 \%$ \\
\hline & $6-10$ & $23 \%$ \\
\hline & $11-15$ & $20 \%$ \\
\hline & $16-20$ & $13 \%$ \\
\hline & $21-40$ & $14 \%$ \\
\hline \multirow{2}{*}{ School ownership } & Public schools * & $67 \%$ \\
\hline & Private/concerted schools ** & $33 \%$ \\
\hline \multirow{2}{*}{ Location of the school } & Rural setting & $32.95 \%$ \\
\hline & Urban setting & $67.1 \%$ \\
\hline
\end{tabular}

* state-funded and civil servant teachers. ${ }^{* *}$ state-funded-families and contract teaching staff.

Table 2. Sample by autonomous regions.

\begin{tabular}{ccc}
\hline Autonomous Regions & Frequency & Percentage \\
\hline Andalucía & 282 & 11.5 \\
Valencia & 132 & 5.4 \\
Murcia & 138 & 5.6 \\
Extremadura & 308 & 12.5 \\
Asturias & 55 & 2.2 \\
Aragón & 261 & 10.6 \\
Baleares & 95 & 3.9 \\
Castilla y León & 284 & 11.6 \\
Cataluña & 370 & 15.1 \\
Madrid & 291 & 11.8 \\
Castilla la Mancha & 174 & 7.1 \\
Galicia & 67 & 2.7 \\
\hline Total & 2.457 & 100.0 \\
\hline
\end{tabular}

The questionnaire was sent to the schools selected in each autonomous community according to the criteria of location (rural or urban) and ownership of the school (public and private or subsidised) to be distributed within them to a random sample of teachers. Data collection was carried out between January and May 2018. The procedure used was via Google-Form. In some cases, it was sent in paper format to the management team of the schools to be collected once completed in order to motivate participation in the study. The data were processed with the consent of all participants, guaranteeing their anonymity. 


\subsection{Data Analysis}

Once the data had been obtained, using the SPSS statistical package, we carried out a study to check whether they conformed to the assumptions of normal distribution (visual inspection of QQ graphs; skewness and kurtosis indices and Kolmogorov-Smirnov statistic). We determine the homogeneity of variances (homoscedasticity) by applying Levene's statistic (results $>0.05$ ). We check that the data met the assumptions necessary for the analysis of variance (ANOVA). Post-hoc tests with the Scheffe and Tukey statistics are also applied to determine the trend in relation to the differences that can be observed between the different categories of socio-demographic variables. Finally, the effect size is calculated using Cohen's d statistic for the different variables.

Likewise, we performed a descriptive statistical analysis, with response percentages by sub-dimensions. We then carried out an exploratory factor analysis (EFA) to determine the fit of items to the three sub-dimensions.

\section{Results}

We begin the descriptive analysis of the data with the response percentages of the items by sub-dimensions. Regarding "Curriculum Design", the sum of percentages 4 and 5 referring to the frequency of "almost always" and "always", indicate that almost $\frac{3}{4}$ of the responding teachers consider that classroom programmed are designed in a flexible way guaranteeing the adjustment to the individual needs of the students (item 10, 71.5\%; item $12,72.6 \%)$. However, with a lower frequency they reflect the interests and motivation of the students (item $11,61 \%$ ).

In the sub-dimension "Methodology" (item 13, 65.4\%; item 14, 64.6\%; and item 15, $65.2 \%$ ), slightly lower percentages are observed in frequencies 4 and 5 regarding the use of methodologies that promote the principles of the SAD. For this reason, it is considered that in order to promote quality inclusive education, it is necessary to deepen the application of active and collaborative methodologies that facilitate interaction between all students.

The last dimension of analysis referred to "Assessment", item 16 on "detecting and identifying the needs of learners with SEN" is the one that obtained the highest proportion of responses $(71.7 \%)$ among teachers. The second item which obtained the greatest consensus $(69.4 \%)$ is item 17 , which shows that the assessment methods and techniques used are adjusted to the individual characteristics of the students. Slightly more than half of the teachers $(62.6 \%)$ consider that the assessment methods and techniques used enable SEN students to demonstrate their abilities (item 18). Finally, the aspect most in need of improvement, only indicated by $56.8 \%$ in categories 4 and 5 combined, is that of facilitating the participation of the different members of the educational community (item 19).

Taking into account the average of all the items $(X=3.75)$, it is worth noting that the items with the highest scores are those referring to curriculum design. More specifically, item 10 with an average of 3.94 (the programming units that are proposed are based on the pupils' prior knowledge) and item 12 (progressive autonomy is promoted in the planning and carrying out of the pupils' work) with an average of 3.91. On the other hand, the item with the lowest score is the item referring to the participation of the different members of the educational community (family, students, and other teachers at the centre) in the assessment process of students with SEN associated with disability, with an average of 3.54.

Standard deviations indicate little dispersion in responses with the exception of item 13 $(\sigma=1.443)$ which indicates greater variability in response (Table 3).

Based on the parameters defined in the questionnaire used, we are going to describe and establish the influence of the variables incorporated in the characterisation or profile of the sample on the processes dominated by curriculum design, methodology, and assessment. 
Table 3. Statistics referring to the items of the questionnaire.

\begin{tabular}{|c|c|c|}
\hline & MEAN & DS \\
\hline \multicolumn{3}{|l|}{ CURRICULUM DESIGN } \\
\hline $\begin{array}{l}\text { 10. The programming units (didactic units, projects, etc.) that are proposed } \\
\text { are based on the students' prior knowledge. }\end{array}$ & 3.94 & 0.947 \\
\hline $\begin{array}{l}\text { 11. Programming units (didactic units, projects, etc.) are adapted to the } \\
\text { interests and motivations of the students. }\end{array}$ & 3.66 & 0.945 \\
\hline $\begin{array}{l}\text { 12. Progressive autonomy is promoted in the planning and carrying out of } \\
\text { students' work. }\end{array}$ & 3.91 & 0.906 \\
\hline \multicolumn{3}{|l|}{ METHODOLOGY } \\
\hline $\begin{array}{l}\text { 13. It is made possible for students to carry out the proposed tasks in a } \\
\text { flexible way using different formats. }\end{array}$ & 3.75 & 1.443 \\
\hline 14. Collaborative work strategies are encouraged among all students. & 3.71 & 0.937 \\
\hline $\begin{array}{l}\text { 15. Support strategies are used in the mainstream classroom for students } \\
\text { with SEN associated with disability. }\end{array}$ & 3.74 & 1.004 \\
\hline \multicolumn{3}{|l|}{ EVALUATION } \\
\hline $\begin{array}{l}\text { 16. The evaluation process that is carried out allows for the detection and } \\
\text { identification of the needs of students with SEN associated with disability } \\
\text { in order to provide them with the appropriate response. }\end{array}$ & 3.85 & 0.896 \\
\hline $\begin{array}{l}\text { 17. Assessment methods and techniques are adapted to the characteristics } \\
\text { of students with SEN associated with disability. }\end{array}$ & 3.81 & 0.913 \\
\hline $\begin{array}{l}\text { 18. The assessment methods and techniques used enable learners with } \\
\text { disability-related SEN to demonstrate their own abilities. }\end{array}$ & 3.68 & 0.915 \\
\hline $\begin{array}{l}\text { 19. In the evaluation process of students with SEN associated with } \\
\text { disability, the participation of the different members of the educational } \\
\text { community (family, students and other teachers of the centre) is facilitated. }\end{array}$ & 3.54 & 1.080 \\
\hline
\end{tabular}

In this section, we will consider the comparative analysis between different variables, so that we can observe the incidence of these variables on the variables assumed as dependent, as expressed previously. It should be noted that the dimension related to perception is analysed from the consideration of each of the items, given the independent character that we confer on each of them from the content analysis.

An analysis of variance (ANOVA) was then carried out to determine whether there are significant differences between the items of the dimensions relating to curriculum design, methodology, and assessment, considered as dependent variables, and different independent variables such as gender, age, teaching experience, experience with students with educational support needs, geographical location of the school, type of school and autonomous community.

With regard to the gender variable, the descriptive analysis allows us to observe a more favourable score for men in some items. However, these differences are minimal as shown by the effect size under Cohen's "d-test", where the results for items 10,11, and 12 reflected a small effect; for example, in item 12 of the "curriculum design" dimension $(F=4.223$, $p=0.04,<0.05$ ) and in all items referring to assessment (item 16, $F=6971, p=0.008,<0.05$; item 17, $F=4353, p=0.03, \leq 0.05$; item 18, $F=3865 p=0.04,<0.05$; item 19, $F=4234$ ， mboxemphp $=0.04,<0.05)$.

In relation to age, statistically significant differences are observed in the items referring to curriculum design (item 10, $F=5.442, p=0.001,<0.05$; item $11, F=5.386, p=0.001$, $<0.05$; item $12, F=4.553 p=0.001,<0.05)$. Only item $13(F=6.504, p=0.001,<0.05)$ of the methodology dimension and almost all the items referring to evaluation (item $17, F=7.155$, $p=0.001,<0.05$; item 18, $F=3.767, p=0.005,<0.05$; item 19, $F=4.661, p \leq 0.001,<0.05$ ) are significant. The observation of the profile of responses according to age allows us to establish 
an increase in the scores for the highest frequency of use, with a significant difference being observed in teachers over 60 years of age and in those under 30 years of age.

The margins of error found by the post-hoc tests $(p=0.000$, Scheffe $<0.001)$ in curriculum design and methodology and $p=0.008$ in post-hoc test Scheffe $<0.05$ in evaluation would reflect that the extreme age ranges condition the greater frequency of implementation of curriculum design, methodology, and evaluation strategies in line with educational inclusion.

In the methodology dimension, teaching experience, we only found significant statistical differences in item 15 "Support strategies are used in the regular classroom for students with SEN associated with disability" ( $F=2.981, p=0.018,<0.05)$. We could, therefore, point out that the years of teaching experience do not condition ore successful educational practices with the diversity of abilities, motivations, and interests of the students.

Regarding the variable teaching experience with students with educational support needs, significant differences are observed in items 10 and 12 referring to curriculum design (item 10, $F=6.812, p=0.001,<0.05$; item 12, $F=3.043, p=0.016,<0.05$ ); item 15 on methodology (item $15, F=7568, p=0.0001,<0.05$ ), and almost all items referring to evaluation (item 16, $F=2518, p=0.04,<0.05$; item 17, $F=2914, p=0.02,<0.05$; item 19, $F=3540, p<0.007,<0.05)$.

Bearing in mind Scheffe's post-hoc tests, it is observed that teachers with more than 21 years' experience with students with SEN score lower mean scores than teachers with 11 to 15 years' experience in the factor of curriculum design and methodology, establishing significant differences $(p=0.043 ;<0.05)$. Consequently, it would be teachers with SEN between 11 and 15 years of experience who are more motivated to make individualised adjustments to the curricular elements necessary for correct teaching with a variety of pupils' educational needs.

In the ownership of the school, significant differences are found in practically all the items, in favour of private or subsidised schools. In the curriculum design dimension, items $10(F=10.198, p=0.001,<0.05)$, item $11(F=10.607, p=0.001,<0.05)$, and item $12(F=9.434$, $p=0.002,<0.05)$ are significant. From the methodology dimension, item $13(F=9.013$, $p=0.003,<0.05)$, item $14(F=18.102, p=0.001,<0.05)$, and item $15(F=5.517, p=0.019$, $<0.05)$ are significant. As far as evaluation is concerned, there are significant differences in almost all items (item 17, $F=5340, p=0.021,<0.05$; item 18, $F=5671, p=0.017,<0.05$; item $19, F=6010, p<0.014,<0.05)$. However, the effect size showed that the effect size was small, with results ranging between 0.18 and 0.16 .

In relation to the geographical location of the school, numerous items are significant, with more favourable responses from urban schools. In the curriculum design dimension, significant differences are found in item $10(F=16.383, p=0.001,<0.05)$, item $11(F=11.321$, $p=0.001,<0.05)$, item $12(F=14.930, p=0.001,<0.05)$. Regarding methodology dimension, only item $13(F=4.978, p=.026,<0.05)$ is significant. As far as evaluation is concerned, significant differences are found in items $16(F=9.379, p=0.002,<0.05)$, item $18(F=6.456$, $p=0.011,<0.05)$, item $19(F=7.926, p=0.005,<0.05)$, and item $18(F=6.456, p=0.011$, $<0.05)$. Based on the data obtained, we could highlight that rural schools are more capable of adapting to the diversity of students' abilities and motivations in the design of their curricula and in the use of assessment methods and instruments.

Finally, the differences between the autonomous communities participating in the study in all dimensions and items are highly significant. ANOVA analysis confirmed these differences $(p=0.001 ;<0.05)$. In relation to the factor curriculum design and methodology, the application of Scheffe's post-hoc tests results in the establishment of statistically significant differences between the Community of Madrid and the Community of Castilla La Mancha. In the same way, the application of Tukey's post-hoc test allows us to observe significant differences between the Community of Madrid and the Communities of Castilla y León, Aragón, and Castilla-La Mancha, as well as between Andalucía, Cataluña, Baleares, and Asturias, which obtain lower results than the Community of Castilla La Mancha. Likewise, in relation to the Evaluation factor, the application of Tukey's post-hoc test shows 
significant differences between Madrid, the Balearic Islands, and Cataluña, with lower scores than Castilla-La Mancha. However, despite the significance of the differences, they are not very large and there may be other associated latent variables that could explain these differences. This is why this research team takes a cautious approach to the interpretation of these results.

\section{Discussion and Conclusions}

As can be seen in the results, the teachers' responses allow us to characterise an optimum level in relation to curriculum design, methodology, and assessment in their educational practice. However, it is possible to identify improvements that could be made, such as those related to the interests and motivations of students with SEN and their participation in assessment.

Observation of the results shows how teachers promote few collaborative work strategies among all students, as Paseka and Schwab [51] had already noted, who demonstrated the promotion of individualised strategies in response to needs. Likewise, with regard to evaluation, it is observed that practices are oriented towards adapting to respond to the needs of students on the basis of the data obtained in the evaluation, orienting themselves, according to Young and Kim [60], towards improving teaching, bearing in mind the role of experience. On the basis of the evaluation results, therefore, organisational and instructional changes are made in response.

The different identification variables taken into consideration in the study show differences worth highlighting. The typology of schools shows that teachers in privatesubsidised schools develop more inclusive practices and show greater agreement on inclusive teaching strategies than teachers in public schools. These results coincide with those reported by Bedi and Garg [5], Chubb and Moe [6] or Colmenero, Pegalajar, and Pantoja [7], and Solís et al. [8].

Similarly, teachers in rural schools show more positive perceptions towards inclusive education than those in urban schools, thus corroborating the study by Solís et al. [8].

In relation to gender, we observe that men teachers have more favourable opinions than women teachers towards inclusive curriculum design, results that coincide with the studies by Colmenero [61], Colmenero, Pegalajar, and Pantoja [7], Alghazo and Naggar [9], Mengual, López, and Viana [10], Parasuram, [11], Polo and Aparicio [12] in which more positive conditions are revealed among men teachers for the development of inclusive practices. These data contradict those collected by Boyle et al. [13], Opdal et al. [62], and Specht et al. [63] who affirm how women not only show better perceptions towards inclusion, but that their strategies are more inclusive.

In terms of age and teaching experience, we find that younger and older teachers are more likely to consider the implementation of inclusive teaching strategies. Older teachers have more favourable perceptions, which is consistent with the studies by Colmenero, Pegalajar, and Pantoja [7]; Avramidis and Norwich [19]; Balboni and Pedrabissi [64]; Leyser and Kirk [20]; Kalyva, Gojkovic, and Tsakiris [22]; Batsiou, Bebetsos, Panteli, and Antoniou [21]; Polo and Aparicio [12]. In contrast to these claims, studies by Forlin, Loreman, Sharma, and Earle [23]; Sharma, Forlin, and Loreman [65], reveal that younger students develop more negative practices towards inclusion.

Teachers should work with students without labels, without classifications, without categorisations, seeking the construction of collaborative work that has a positive impact on the development of students in a cultural context, through the use of guidelines and adapted strategies.

The results obtained in relation to methodology indicate that we are currently working on the basis of differentiated instruction, making the performance of proposed tasks more flexible through modifications in learning activities, which would be in line with the approaches of Suprayogi and Valcke [66], content, assessment methods and the classroom environment in order to respond to the needs of each student, acting reactively to special educational needs [50]. 
In relation to methodological strategies, the results indicate that cooperative learning is generally favoured as a significant strategy in the field of inclusive education, in line with the studies of Tzivinikoua and Papoutsakib [48], Sabando et al. [49], and Lindner and Schwab [50].

As far as support strategies in the mainstream classroom are concerned, the results obtained show that the approach used corresponds to an individualised instructional approach. Thus responding to the individual educational needs of each student, from a reactive perspective as pointed out by Lindner and Schwab [50].

Finally, at the methodological level, it can be considered that, although the current models present both differential and individual approaches, the working perspective, as the results show, is directed towards an approach based on Universal Design for Learning (UDL). This is due to its proactive nature, where access and participation of all learners is guaranteed [41]. Therefore, in the classroom, UDL embedded practices are an opportunity to positively influence the success of inclusion [52], considering that UDL has been evolving towards a more flexible model with customisable options, ready to address individual needs [41]. Furthermore, as Young and Kim [60] state in relation to assessment, "the ability of teachers to incorporate these new practices depends in part on their day-to-day classroom management skills to regulate the flow of activity and interactions within the classroom community".

Although in the results we have taken into account variables, such as the ownership of the centre and the differentiation of autonomous community, we must be cautious with regard to comparisons, as noted in the results. Given that the sample used corresponds overwhelmingly to public schools, the comparative bias with private or subsidised schools should lead us to avoid generalisations regarding the differences found in their favour.

Studying how teachers approach the teaching-learning process from the perspective of inclusion can contribute not only to identifying teachers' preferences, but also the various barriers and impediments in order to implement changes aimed at improving the process.

Author Contributions: Conceptualization, P.J.-d.-l.-S., M.J.C.-R., R.E.V.-F., M.C.-L. and V.F.-C.; Formal analysis, P.J.-d.-l.-S., M.J.C.-R., R.E.V.-F., M.C.-L. and V.F.-C.; Investigation, P.J.-d.-l.-S., M.J.C.-R., R.E.V.-F., M.C.-L. and V.F.-C.; Methodology, P.J.-d.-1.-S., M.J.C.-R. and R.E.V.-F.; Resources, P.J.-d.-1.-S., M.J.C.-R., R.E.V.-F., M.C.-L. and V.F.-C.; Supervision, P.J.-d.-1.-S., M.J.C.-R. and R.E.V.-F.; Validation, M.J.C.-R. and R.E.V.-F.; Visualization, M.J.C.-R. and R.E.V.-F.; Writing-original draft, P.J.-d.-l.-S., M.J.C.-R., R.E.V.-F., M.C.-L. and V.F.-C.; Writing-review \& editing, P.J.-d.-1.-S., M.J.C.-R. and R.E.V.-F. All authors have read and agreed to the published version of the manuscript.

Funding: This research was funded by the R + D + I project of the national call of the Spanish government EDU2016-75574-P. “Study on educational response to students with Specific Educational Support Needs Associated with Disability".

Institutional Review Board Statement: The study was conducted according to the guidelines of the Declaration of Helsinki, and approved by the Institutional Review Board (or Bioethics Committee) of the University of Almeria (Ref. UALBIO 2019/039), that it is demanded for de research EDU201675574-P.

Informed Consent Statement: Informed consent was obtained from all subjects involved in the study.

Data Availability Statement: Research data are currently available on the website, while the ministerial repository publishes the research data.

Acknowledgments: We would like to thank the teachers of the participating schools for their disinterested collaboration in this study in order to obtain the data.

Conflicts of Interest: The authors declare no conflict of interest. 


\section{References}

1. UN. The Sustainable Development Goals Report 2020. Available online: https://unstats.un.org/sdgs/report/2020/TheSustainable-Development-Goals-Report-2020.pdf (accessed on 30 November 2020).

2. UNESCO. Declaración de Salamanca y Marco de Acción sobre Necesidades Educativas Especiales Aprobada en la Conferencia Mundial sobre Necesidades Educativas Especiales: Acceso y Calidad; Ministerio de Educación y Ciencia: Salamanca, Spain, 1994. Available online: https: / / unesdoc.unesco.org/ark:/48223/pf0000098427_spa?posInSet=2\&queryId=6398731e-3ddc-4747-8641-416f030 9 ca78 (accessed on 15 October 2020).

3. UNESCO. Compromiso de Cali sobre Equidad e Inclusión en la Educación Aprobado en el Foro Internacional sobre Inclusión y Equidad en la Educación; UNESCO: Cali, Colombia, 2019. Available online: https://unesdoc.unesco.org/ark:/48223/pf0000370910_spa?fbclid= IwAR0U0FUCDgStZU-ZeYZ7_82A2_5SpLwjQcUBG7LYSQVTgwHCl3tkSGjNpKw (accessed on 15 October 2020).

4. Ley 2/2006, de 3 de Mayo, de Educación. Boletín Oficial del Estado; Núm. 106, 04 de Mayo de 2006. Available online: https:/ / noticias.juridicas.com/base_datos/Admin/lo2-2006.html (accessed on 15 October 2020).

5. Bedi, A.S.; Garg, A. The effectiveness of private versus public schools: The case of Indonesia. J. Dev. Econ. 2000, 61, 463-494. [CrossRef]

6. Chubb, J.E.; Moe, T.M. Politics, markets and the organization of schools. Am. Polit. Sci. Rev. 1990, 82, 1066-1087. [CrossRef]

7. Colmenero, M.J.; Pegalajar, M.C.; Pantoja, A. Percepción del profesorado sobre prácticas docentes inclusivas en alumnado con discapacidades graves y permanentes. Cult. Educ. 2019, 31, 542-575. [CrossRef]

8. Solís, P.; Pedrosa, I.; Mateos-Fernández, L.M. Assessment and interpretation of teachers' attitudes towards students with disabilities. Cult. Educ. 2019, 31, 576-608. [CrossRef]

9. Alghazo, E.; Naggar, E. General education teachers in the United Arab Emirates and their acceptance of the inclusion of students with disabilities. Br. J. Spec. Educ. 2004, 31, 94-99. [CrossRef]

10. Mengual, S.; López, M.; Viana, M.I. Future Pedagogues' attitudes and knowledge about inclusive education in Spain: An exploratory study. Rev. Eur. Stud. 2015, 7, 103-114.

11. Parasuram, K. Variables that affect teachers' attitudes towards disability and inclusive education in Mumbai, India. Disabil. Soc. 2006, 21, 231-242. [CrossRef]

12. Polo, M.T.; Aparicio, M. Primeros pasos hacia la inclusión: Actitudes hacia la discapacidad de docentes en educación infantil. Rev. Investig. Educ. 2018, 36, 365-379. [CrossRef]

13. Boyle, C.; Topping, K.; Jindal-Snape, D. Teachers' attitudes towards inclusion in high school, teachers and teaching. Teach. Teach. Theory Pract. 2013, 19, 527-542. [CrossRef]

14. Forlin, C.; Sharma, U.; Loreman, T. An international comparison of pre-service teacher attitudes towards inclusive education. Disabil. Stud. Q. 2007, 27, 1-13.

15. Gao, W.; Mager, G. Enhancing preservice teachers' sense of efficacy and attitudes toward school diversity through preparation: A case of one US inclusive teacher education program. Int. J. Spec. Educ. 2011, 26, 92-107.

16. Kim, J. Influence of teacher preparation programmes on preservice teachers' attitudes toward inclusion. Int. J. Inclus. Educ. 2011, 15, 355-377. [CrossRef]

17. Swain, K.D.; Nordness, P.D.; Leader-Janssen, E.M. Changes in preservice teacher attitudes toward inclusion. Prev. Sch. Fail. 2012, 56, 75-81. [CrossRef]

18. Tárraga, R.; Grau, C.; Peirat, J. Actitudes de los estudiantes del Grado de Magisterio y del Máster de Educación Especial hacia la inclusión educativa. Rev. Electrón. Interuniv. Form. Profr. 2013, 16, 55-72.

19. Avramidis, E.; Norwich, B. Teachers' attitudes towards integration/inclusion: A review of the literature. Eur. J. Spec. Needs Educ. 2002, 17, 129-147. [CrossRef]

20. Leyser, Y.; Kirk, R. Evaluating inclusion: An examination of parent views and factors influencing their perspectives. Int. J. Disabil. Dev. Educ. 2004, 51, 271-285. [CrossRef]

21. Batsiou, S.; Bebetsos, E.; Panteli, P.; Antoniou, P. Attitudes and intention of Greek and Cypriot primary education teachers towards teaching pupils with special educational needs in mainstream schools. Int. J. Inclus. Educ. 2008, 12, 201-219. [CrossRef]

22. Kalyva, E.; Gojkovic, D.; Tsakiris, V. Serbian teachers' attitudes towards inclusion. Int. J. Spec. Educ. 2007, 22, 31-36.

23. Forlin, C.; Loreman, T.; Sharma, U.; Earle, C. Demographic differences in changing pre-service teachers' attitudes, sentiments and concerns about inclusive education. Int. J. Inclus. Educ. 2009, 13, 195-209. [CrossRef]

24. Forlin, C.; Chambers, D. Teacher preparation for inclusive education: Increasing knowledge but raising concerns. Asia Pac. J. Teach. Educ. 2011, 39, 17-32. [CrossRef]

25. Kwon, K.A.; Hong, S.Y.; Jeon, H.J. Classroom readiness for successful inclusion: Teacher factors and preschool children's experience rith and attitudes toward peers with disabilities. J. Res. Child. Educ. 2017, 31, 360-378. [CrossRef]

26. Martínez, M.A.; Bilbao, M.C. Los docentes de la universidad de Burgos y su actitud hacia las personas con discapacidad. Rev. Española Discapac. Intelect. 2011, 42, 50-78.

27. Muratori, M.; Guntín, C.; Delfino, G. Actitudes de los adolescentes hacia personas con discapacidad: Un estudio con alumnos de plimodal en la zona norte del conurbano bonaerense. Rev. Psicol. 2010, 6, 39-56.

28. Boer, A.; Jan, S.; Minnaert, A. Regular primary school teachers' attitudes towards inclusive education: A review of the literature. Int. J. Inclus. Educ. 2011, 15, 331-353. [CrossRef] 
29. Casanova, M.A. Diseño curricular para la educación inclusiva. In Voces de la Inclusión. Interpelaciones y Críticas a la Idea de "Inclusión" ; Ramírez, I.E., Ed.; Voces de la Educación: Veracruz, Mexico, 2016; pp. 90-108.

30. Wehmeyer, M.L. Autodeterminación y la tercera generación de prácticas de inclusión. Rev. Educ. 2009, 349, 45-57.

31. Nilsen, S. Special education and general education—coordinated or separated? A study of curriculum planning for pupils with special educational needs. Int. J. Incl. Educ. 2016, 21, 205-217. [CrossRef]

32. Buli-Holmberg, J.; Kamenopoulou, L. Attaining New Knowledge on Inclusive Education: A Case Study of Students' Voices. Athens J. Educ. 2017, 4, 363-378. [CrossRef]

33. Maphefo, J.; Joyce, M. Flexibility of the Curriculum. In Inclusive Education: An African Perspective; Phasha, N., Condy, J., Eds.; Oxford University Press: Oxford, UK, 2018; pp. 220-238.

34. Arnáiz, P. Educación Inclusiva: Una Escuela para Todos ; Aljibe: Málaga, Spain, 2003.

35. Fernández, P. ¿Cómo se dan los Derechos Educativos de los Niños, Niñas y Adolescentes con Discapacidad en el Perú? Estudio Cualitativo en Huancavelica y Villa el Salvador; Foro Educativo: Lima, Perú, 2007.

36. Forteza, D. La formación del profesorado en y para la educación inclusiva desde la perspectiva de la convergencia europea. In Libro de Actas del II Congreso Iberoamericano sobre el Síndrome de Down: La Fuerza de la Visión Compartida; Federación Española de Síndrome de Down; Real Patronato sobre Discapacidad y Ministerio de Sanidad, Política Social e Igualdad: Madrid, Spain, 2010; pp. 407-420.

37. Sancho, C. Propuestas inclusivas de mejora desde un enfoque metodológico y organizacional. Rev. Latinoam. Educ. Inclus. 2013, 1, 135-149.

38. Kurth, J.A.; Miller, A.L.; Toews, S.G. Preparing for and implementing effective inclusive education with participation plans. Teach. Except. Child. 2020, 53, 140-149. [CrossRef]

39. CAST. Universal Design for Learning Guidelines. Available online: http://udlguidelines.cast.org/ (accessed on 13 September 2020).

40. Sánchez, S.; Díez, E.; Verdugo, M.A.; Iglesias, A.; Calvo, I. Atención a la diversidad en las titulaciones adaptadas al RD 1393/2007: Adaptación de una herramienta Web de autoevaluación curricular basada en los principios del diseño universal para el aprendizaje. In Jornadas de Innovación Docente en la Universidad de Salamanca; Heras, J.L., Peinado, M., Pereira, D., Rodríguez, J.A., Eds.; Universidad de Salamanca: Salamanca, Spain, 2011; pp. 148-155.

41. Griful-Freixenet, J.; Struyven, K.; Vantieghem, W.; Gheyssens, E. Exploring the Interrelationship between Universal Design for Learning (UDL) and Differentiated Instruction (DI): A Systematic Review. Educ. Res. Rev. 2020, 29, 1-57. [CrossRef]

42. Guerrero, C. Hacia la construcción de procesos y prácticas "exclusivas": Metodologías para la intervención. Quad. Animat. Educ. Soc. 2012, 16, 1-16.

43. Echeita, G.; Simón, C.; Verdugo, M.A.; Sandoval, M.; López, M.; Calvo, I.; González-Gil, F. Paradojas y dilemas en el proceso de inclusión educativa en España. Rev. Educ. 2009, 349, 153-178.

44. Florian, L.; Beaton, M. Inclusive pedagogy in action: Getting it right for every child. Int. J. Inclus. Educ. 2017, 22, 870-884. [CrossRef]

45. Florian, L.; Black-Hawkins, K.; Rouse, M. Achievement and Inclusion in Schools, 2nd ed.; Routledge: London, UK, 2017.

46. Gaitas, S.; Alvés, M. Teacher perceived difficulty in implementing differentiated instructional strategies in primary school. Int. J. Inclus. Educ. 2016, 21, 544-556. [CrossRef]

47. Mendioroz, A.M.; Rivero, P.; Aguilera, E. Una propuesta de formación docente para responder a las altas capacidades en la escuela inclusiva. Profr. Rev. Curríc. Form. Profr. 2019, 23, 265-284. [CrossRef]

48. Tzivinikoua, S.; Papoutsaki, K. Studying teaching methods, strategies and best practices for young children with special educational needs. Early Child Dev. Care 2015, 186, 971-980. [CrossRef]

49. Sabando, D.; Puigdellívol, I.; Torrado, M. Measuring the Inclusive profile of public elementary schools in Catalonia. Int. J. Educ. Res. 2019, 96, 1-20. [CrossRef]

50. Lindner, K.-T.; Schwab, S. Differentiation and individualisation in inclusive education: A systematic review and narrative synthesis. Int. J. Inclus. Educ. 2020, 1-21. [CrossRef]

51. Paseka, A.; Schwab, S. Parents' attitudes towards inclusive education and their perceptions of inclusive teaching practices and resources. Eur. J. Spec. Needs Educ. 2019, 35, 254-272. [CrossRef]

52. Deneen, C.; Brown, G.T.L. The impact of conception of assessment on assessment literacy in a teacher education program. Cogent Educ. 2016, 3, 1225380. [CrossRef]

53. Anijovich, R.; Cappelletti, G. La Evaluación Como Oportunidad; Paidós: Buenos Aires, Argentina, 2017.

54. Booth, T.; Ainscow, M. Index for Inclusion: Developing Learning and Participation in Schools; Centre for Studies on Inclusive Education: Bristol, UK, 2002.

55. García, M.P. La Evaluación de Programas en la Intervención Socioeducativa; DM: Murcia, Spain, 2003.

56. Bisquerra, R. Metodología de la Investigación Educativa; La Muralla: Madrid, Spain, 2004.

57. Martínez, R.A. La Investigación en la Práctica Educativa: Guía Metodológica de Investigación para el Diagnóstico y Evaluación en los Centros Docentes; Ministerio de Educación y Ciencia: Madrid, Spain, 2007.

58. Murray, K.B. A test or services marketing theory: Consumer information acquisition activities. J. Mark. 1991, 55, 10-25. [CrossRef]

59. Prieto, G.; Delgado, A.R. Fiabilidad y Validez. Pap. Psicól. 2010, 31, 67-74.

60. Young, V.M.; Kim, D.H. Using assessments for instructional improvement: A literature review. Educ. Policy Anal. Arch. 2010, 18, 1-36. [CrossRef] 
61. Colmenero, M.J. Estudio que los Profesores de Educación Secundaria Obligatoria de la Provincia de Jaén Tienen en Torno a la Atención a Alumnos con Necesidades Educativas Especiales: Necesidades Formativas. Ph.D. Thesis, University of Jaen, Jaen, Spain, 2005.

62. Opdal, L.R.; Wormnaes, S.; Habayeb, A. Teachers' opinions about inclusion: A pilot study in a Palestinian context. Int. J. Disabil. Dev. Educ. 2001, 48, 143-162. [CrossRef]

63. Specht, J.; McGuie, D.; Loreman, T.; Mirenda, P.; Bennett, S.; Gallagher, T.; Cloutier, S. Teaching in inclusive classrooms: Efficacy and beliefs of Canadian preservice teachers. Int. J. Inclus. Educ. 2016, 20, 1-15. [CrossRef]

64. Balboni, G.; Pedrabissi, L. Attitudes of Italian teachers and parents toward school inclusion of students with mental retardation: The role of experience. Educ. Train. Ment. Retard. Dev. Disabil. 2000, 35, 48-59.

65. Sharma, U.; Forlin, C.; Loreman, T. Impact of training on pre-service teachers' attitudes and concerns about inclusive education and sentiments about persons with disabilities. Disabil. Soc. 2008, 23, 773-785. [CrossRef]

66. Suprayogi, M.N.; Valcke, M. Differentiated instruction in primary schools: Implementation and challenges in Indonesia. Int. Sci. Res. J. 2016, 72, 1-18. [CrossRef] 